Vol. 1 No. 3 September 2021

\title{
ANALISIS EFEKTIVITAS DANA DESA DI KECAMATAN GUNUNG SARI KABUPATEN LOMBOK BARAT
}

\author{
Uyunul Hikmah \\ uyunul.hikmah11@gmail.com \\ Jurusan Akuntansi Fakultas Ekonomi dan Bisnis Universitas Mataram \\ Wirawan Suhaedi \\ wirawan.suhaedi@unram.ac.id \\ Jurusan Akuntansi Fakultas Ekonomi dan Bisnis Universitas Mataram \\ Intan Rakhmawati \\ intanrakhmawati@unram.ac.id \\ Jurusan Akuntansi Fakultas Ekonomi dan Bisnis Universitas Mataram
}

\begin{abstract}
ABSTRAK
Penelitian ini bertujuan untuk mengetahui tingkat efektivitas dana desa serta faktor- faktor penentu efektivitas dana desa dengan menggunakan variabel pengelolaan keuangan desa, pendapatan desa, dan belanja desa dalam melihat tingkat efektivitas dana desa, serta mengunakan variabel struktur organisasi, sumber daya manusia, teknologi, dan dukungan kepada aparatur desa dalam melihat faktor-faktor penentu efektivitas dana desa. Penelitian ini dilakukan di lima desa pada Kecamatan Gunung Sari, Kabupaten Lombok Barat. Teknik pengumpulan data yang digunakan, yaitu wawancara semi terstruktur mendalam, observasi, dan dokumentasi. Hasil penelitian ini menunjukkan bahwa (1) tingkat efektivitas dana desa sebesar $77 \%$ termasuk dalam kategori kurang efektif karena dalam tahap pegelolaan dana desa masih sering terlambat dilakukan dan masih banyak kegiatan desa yang belum terealisasikan. (2) faktor-faktor penentu efektivitas dana desa seperti struktur organisasi, teknologi, dan dukungan pada aparatur desa sudah memadai, namun ada satu faktor yang belum memadai yaitu sumber daya manusia.
\end{abstract}

Kata kunci: Efektivitas, Dana Desa, Faktor-Faktor Penentu Efektivitas, Pengelolan Keuangan Desa, Pendapatan Desa, Belanja Desa.

\section{PENDAHULUAN}

Dana Desa adalah dana dari Anggaran Pendapatan dan Belanja Negara (APBN) yang diberikan kepada desa dengan cara ditransfer dari Rekening Kas Umum Negara (RKUN) ke Rekening Kas Desa (RKD). Terdapat 5 program prioritas Dana Desa pada tahun 2019 yaitu pertama program di bidang pembangunan dan pemberdayaan masyarakat desa, kedua program yang bersifat lintas bidang, ketiga program pembuatan embung air desa, keempat pembangunan sarana olahraga dan kelima program pembangunan Badan Usaha Milik Desa (BUMDes). Dana desa dikatakan efektif apabila seluruh program yang ditetapkan telah tercapai sesuai dengan yang ditargetkan atau diharapkan. Penelitian Kambey (2015) mengatakan bahwa efektivitas dapat diukur dari beberapa hal, salah satunya yaitu ketepatan penentuan waktu. Tepat waktu akan mempengaruhi tingkat keefektivitasan suatu program atau kegiatan dalam mencapai tujuan. Kegitan yang harus dilakukan secara tepat waktu dapat dimulai dari perencanaan sampai dengan pertanggung jawabannya.

Selain itu, berdasarkan obsevasi awal peneliti di Desa Jeringo Kecamatan Gunung Sari sampai dengan Bulan April 2019, Dana Desa belum dapat dicairkan karena belum menetapkan APBDes tahun 2019 dan belum menyerahkan laporan pertanggungjawaban 
APBDes tahun 2018. Padahal salah satu syarat laporan pertanggungjawaan Dana Desa tahap I adalah sudah menetapkan APBDes, karena desa sendiri dalam menggunakan Dana Desa berdasarkan pada APBDes. Dilihat dari beberapa masalah yang ada di Kecamatan Gunung Sari, Kabupaten Lombok Barat yaitu salah satunya adalah terlambatnya pelaporan pertanggungjawaban APBDes, sehingga peneliti tertarik untuk melakukan penelitian dengan topik analisis efektivitas Dana Desa di Kecamatan Gunung Sari, Kabupaten Lombok Barat.

\section{METODE PENELITIAN}

Jenis penelitian yang digunakan dalam penelitian ini adalah penelitian deskriptif pendekatan kualitatif menggunakan mixed methods dengan desain konvergen, yaitu suatu penelitian yang menggabungkan antara metode kuantitatif dan kualitatif untuk digunakan secara bersama-sama dalam suatu kegiatan penelitian, sehingga data yang diperoleh lebih valid dan reliabel (Sugiyono, 2017:555). Teknik pengumpulan data dalam penelitian ini adalah yang pertama wawancara semi struktural yang dilakukan wawancara langsung kepada informan terkait penelitian yang dilakukan. Yang kedua observasi yang dilakukan pada penelitian ini yaitu peneliti ingin mengamati apakah pengelolaan Dana Desa sudah sesuai dengan aturan yang berlaku mulai dari pelaporan sampai dengan pertanggungjawaban yang dilakukan oleh aparat desa yang ada di beberapa desa Kecamatan Gunung Sari, Kabupaten Lombok Barat. Yang terakhir yaitu dokumentasi yang dikumpulkan dalam penelitian ini yakni Rencana Kerja Pemerintah Desa (RKPDes) dan laporan pertanggungjawaban realisasi pelaksanaan APBDes. Ketiga proses pengumpulan data ini dilakukan secara bersamaan.

Analisis data yang digunakan untuk menguji keabsahan data yaitu Triangulasi antar informan yang dalam penelitian ini peneliti menguji data yang didapat dari informan dengan membandingkan antara satu informan dengan informan lainnya. Data yang diperoleh dari informan tersebut kemudian didiskripsikan, dikategorikan, dan melihat mana pandangan yang sama dan berbeda (Sugiyono, 2017: 519). Selain itu, digunakan juga triangulasi antar variabel yang mengecek data pada setiap variabel dengan menggunakan metode yang berbeda-beda yaitu metode observasi, dokumentasi, dan wawancara.

\section{HASIL DAN PEMBAHASAN}

Analisis efisiensi Dana Desa Jika dilihat dari tahap pengelolaan keuangan desa khususnya pada proses perencanaan desa, 5 Desa yang menjadi sampel sudah melakukan perencanaan sesuai dengan kebutuhan desa. Selain itu, dalam setiap kegiatan yang dilakukan harus memiliki Rencana Anggaran Biaya (RAB) terlebih dahulu. Jika tidak memiliki Rencana Anggaran Biaya, maka kegiatan tersebut tidak dapat dilakukan. Dalam proses pelaksanaan, Tim Pelaksana Kegiatan (TPK) harus memiliki acuan kerja sebagai pedoman mereka dalam melaksanakan kegiatan. Acuan kerja ini akan membantu pemerintah desa dalam melaksanakan tugas apa saja yang harus mereka lakukan. Acuan kerja yang digunakan oleh beberapa desa dalam melaksanakan kegiatan yaitu Anggaran Pendapatan dan Belanja Desa (APBDes) dan RKPDes (Rencana Kerja Pemerintah Desa).

Pelaksanaan kegiatan juga dapat dikatakan efisien jika sudah melakukan kegiatan secara tepat waktu atau tidak melebihi batas waktu yang telah ditentukan. Desa Sesela dalam melaksanakan kegiatan pernah mengalami keterlambatan, hal tersebut terjadi karena beberapa faktor salah satunya keterlambatan pencairan Dana Desa yang mempengaruhi juga 
waktu pelaksanaan kegiata. Dalam pengelolaan keuangan desa salah satunya ada penata usahaan. Penatausahaan dikelola menggunakan aplikasi Siskeudes. Aplikasi ini digunakan untuk memudahkan dalam mencatat penerimaan dan pengeluaran desa. Siskeudes biasanya sering digunakan oleh kaur keuangan untuk menyusun APBDes sampai dengan membuat laporan pertanggungjawaban APBDes. Selain itu, seluruh desa sudah menggunakan aplikasi Siskeudes dalam proses penatausahaan. Aplikasi Siskeudes digunakan untuk membuat dokumen-dokumen yang dibutuhkan dalam proses perencanaan sampai dengan pertanggungjawaban.

Dari penjelasan di atas, dapat disimpulkan bahwa pemerintah Desa sudah mengelola Dana Desa secara efisien jika dilihat dari tahap perencanaan dan penatausahaannya karena sudah membuat perencanaan dan penganggaran sesuai dengan kebutuhan desa. Jika dilihat dari penatausahaannya sudah menggunakan aplikasi siskeudes yang membuat penatausahaannya lebih baik dan rapi dari sebelumnya. Sedangkan jika dilihat dari proses pelaksanaannya masih belum efisien karena sering mengalami keterlambatan pelaksanaannya terutama dalam bidang pembangunan desa. Hal itu terjadi karena terlambatnya pencairan Dana Desa, sehingga terlambat juga proses pelaksanaanya. Oleh karena itu, efisiensi Dana Desa di Kecamatan Gunungsari bisa dikatakan belum efisien karena belanja desa semakin berkurang atau sedikit bukan karena pengelolaannya yang efisien melainkan ada kegiatan yang belum terlaksana, sehingga belanjanya semakin berkurang. Selain itu, dalam hal pelaksanaan kegiatannya juga masih sering terlambat dilaksanakan atau tidak sesuai dengan waktu yang telah ditetapkan. Hal tersebut semakin membuat pengelolaan Dana Desa semakin tidak efisien.

Sedangkan analisis efektivitas pendapatan Dana Desa, Dari hasil riset, peneliti menemukan bahwa ada beberapa faktor yang menyebabkan realisasi pendapatan Dana Desa lebih kecil dari anggarannya. Faktor pertama yaitu karena ada beberapa kegiatan pada tahun sebelumnya yang belum terlaksana. Belum terlaksananya beberapa kegiatan tersebut, mengakibatkan desa mendapat sanksi dipotong atau dikurangi pendapatan Dana Desa tahun berikutnya. Oleh karena itu, kecilnya realisasi pendapatan Dana Desa di Desa Sesela disebabkan karena sanksi tidak melaksanakan beberapa kegiatan di tahun sebelumnya. Faktor kedua yaitu dilihat dari Indek Desa Membangun (IDM), semakin maju desa maka akan semakin sedikit Dana Desa yang diterima, begitu juga sebaliknya semakin tertinggal desa maka akan semakin banyak juga Dana Desa yang diterima. Sedikitnya Dana Desa yang diterima oleh Desa disebabkan karena Desa termasuk dalam kategori Desa Maju yang dianggap bisa atau mampu mengelola desanya dan pendapatan asli desanya cukup tinggi.

Faktor ketiga yaitu jika dilihat dalam proses laporan pertanggungjawban terkadang masih terlambat, hal itu akan membuat terlambat juga pencairan Dana Desa sehingga dalam merealisasikan kegiatannya juga sering terlambat, bahkan tidak bisa direalisasikan kareana waktu yang dibutuhkan tidak mencukupi, terutama dalam pembangunan yang besar seperti pembangunan jalan dan jembatan. Berdasarkan penjelasan di atas, dapat disimpulkan bahwa pendapatan Dana Desa belum efektif karena beberapa faktor yaitu yang pertama karena ada beberapa kegiatan pada tahun sebelumnya yang belum terealisasi yang mengakibatkan Desa mendapatkan sanksi. Faktor kedua yaitu karena Desa termasuk dalam kategori Desa Maju yang memiliki pendapatan asli desa yang cukup tinggi, dan faktor yang terakhir yaitu dalam proses pelaksanaan dan pertanggungjawabannya belum dilakukan secara tepat waktu. Hal tersebut membuat pencairan Dana Desanya juga terlambat sehingga ada kegiatan yang belum 
terealisasikan karena kurangnya waktu yang digunakan untuk merealisasikan kegiatan tersebut. Dari beberpa faktor tersebut membuat Dana Desa yang diterima semakin berkurang atau tidak sama dengan yang dianggarkan. hal tersebut membuat pendapatan Dana Desa menjadi tidak efektif.

Selain itu, analisis efektivias belanja Dana Desa termasuk dalam kategori kurang efektif karena anggaran lebih besar daripada realisasinya. Itu berarti belanja desa tidak mencapai anggaran atau tidak mencapai tujuan yang telah ditetapkan. Hal tersebut terjadi karena ada bebrapa kegiatan yang belum terealisasikan. Belum direalisasikannya kegiatan tersebut disebabkan karena aparatur desa lebih fokus terhadap bidang yang lain, sehingga lupa dan tidak ada waktu untuk melakukan kegiatan tersebut. Berdasarkan penjelasan di atas, dapat disimpulkan bahwa Belanja Dana Desa belum efektif karena masih ada belanja yang belum terealisasikan karena ada beberapa kegiatan yang tidak terlaksana. Kegiatan tersebut tidak bisa dilaksanakan karena pemerintah desa hanya fokus terhadap satu kegiatan saja, sehingga mengabaikan kegiatan yang lain yang mengakibatkan tidak terlaksananya kegiatan tersebut.

Faktor-faktor penentu efektivitas yaitu faktor struktur organisasi seperti pembagian tugas dan peranan secara baik sesuai dengan peraturan yang berlaku, uraian tugas yang diberikan jelas dan lengkap dan pengaturan wewenang oleh pimpinan secara jelas. Faktor Sumber Daya Manusia seperti pemahaman mereka mengenai aturan keuangan desa, kemampuan mereka dalam mengelola keuangan dan pemahaman mengenai Dana Desa.

Faktor Teknologi seperti siskeudes mempermudah proses pengelolaan keuangan desa dan mempercepat proses pengelolaan keuangan desa. Faktor Dukungan Pada Aparatur Dan Pelaksanaannya, seperti keterlibatan atau ikut serta masyarakat dan tokoh masyarakat dalam Musdes dan Musrenbangdes dan pemberian pelatihan oleh pemerintah daerah terkait dengan pengelolaan keuangan desa.

\section{KESIMPULAN}

Efisiensi Dana Desa di Kecamatan Gunungsari, Kabupaten Lombok Barat mayoritas desa sudah efisien jika dilihat dari belanja desa yang lebih kecil dibandingkan dengan pendapatannya. Namun hal tersebut terjadi karena ada beberapa kegiatan yang belum terealisasikan sehingga belanjanya berkurang. Oleh karena itu, Dana Desa di Kecamatan Gunungsari belum bisa dikatakan efisien karena belum bisa mengelola belanjanya agar lebih efisien tanpa harus mengurangi kegiatan yang ada.

Sedangkan efektivitas pendapatan Dana Desa di Kecamatan Gunungsari kurang efektif karena pendapatan yang diterima tidak sama dengan yang di anggarkan. Dari 5 sampel yang ada, 3 desa (Desa Sesela, Desa Jeringo, Desa Gelangsar) termasuk dalam kategori pendapatannya kurang efektif. Tidak efektifnya pendapatan Dana Desa

tersebut disebabkan oleh beberapa faktor, yang pertama karena banyak kegiatan yang belum terealisasikan pada tahun sebelumnya terutama di bidang pembangunan dan pemberdayaan masyarakat, sehingga desa-desa tersebut mendapatkan sanksi berupa pemotongan pendapatan Dana Desa pada tahun berikutnya. Faktor kedua karena pengalokasian Dana Desa berdasarkan Indeks Desa Membangun (IDM), sehingga Dana Desa yang paling banyak di berikan kepada Desa Tertinggal dan paling sedikit diberikan pada Desa Maju. Faktor yang ketiga yaitu karena laporan pertanggungjawaban yang terlambat dilaporakan sehingga dapat menyebabkan terlambat juga melaksanakan kegiatan yang lain dan mengakibatkan terkana 


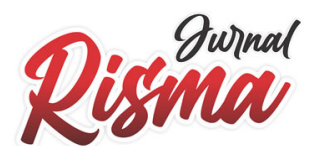

Vol. 1 No. 3 September 2021

sanksi lagi. Faktor terakhir karena terlalu banyak kegiatan yang direncanakan oleh aparatur desa sehingga membuat mereka kebingungan harus mendahulukan yang mana dan menyebabkan ada beberapa kegiatan yang tidak terlaksana.

Selain itu, efektivitas Belanja Dana Desa di Kecamatan Gunungsari termasuk juga dalam kategori kurang efektif kareana seluruh sampel desa menujukkan bahwa realisasi belanjanya selalu lebih sedikit dari anggarannya. Hal tersebut terjadi karena ada beberapa belanja yang tidak direalisasikan. Ada beberapa faktor yang membuat hal tersebut terjadi, yang pertama yaitu karena Dana Desa yang terlambat dicairkan sehingga membuat terlambat juga melaksanakan kegiatan-kegiatan tersebut karena waktu yang dibutuhkan tidak cukup seperti untuk membangun jalan atau jembatan. Terlebih lagi sulit mencari tenaga kerja untuk membuat bangunan tersebut, karena gempa yang terjadi membuat semua masyarakat desa lebih fokus untuk membangun rumah masing-masing. Faktor yang kedua yaitu karena para aparatur desa lebih fokus atau mendahulukan kegiatan di bidang lain, sehingga mengabaikan kegiatan yang belum terealisasikan tersebut. Terlebih lagi kegiatan yang direncanakan tidak sedikit, sedangkan aparatur desa hanya berjumlah minimal 8 orang yang harus melaksanakan seluruh kegiatan tersebut. hal tersebut membuat aparatur desa terkadang kebingungan harus mendahulukan yang mana. Faktor yang terakhir yaitu karena aparatur desa menganggarkan belanja dan kegiatan lebih tinggi dibandingkan dengan pendapatannya, hal tersebut membuat belanja desa tidak efektif karena tidak sesuai antara yang dianggarkan dengan pendapatan yang diterima.

Belum efektifnya pengelolaan Dana Desa ini juga dapat disebabkan oleh faktor sumber daya manusianya. Hal ini dikarenakan masih kurangnya pemahaman para aparatur desa tentang keuangan desa serta masih kurangberkompetennya sumber daya pemerintah desa dalam pengelolaan keuangan desa. Selain faktor yang menghambat efektivitas Dana Desa, ada beberapa faktor juga yang mendukung proses pengelolaan Dana Desa yaitu faktor struktur organisasi atau pembagian peran dan tugas secara baik, faktor teknologi seperti Siskeudes yang memudahkan dan mempercepat pembuatan dokumen mulai dari tahap perencanaan sampai dengan pertanggungjawabannya, serta faktor dukungan kepada aparatur desa, dengan memberikan pelatihan sehingga dapat meningkatkan kemampuan aparatur desa dalam mengelola keuangan desa.

\section{KETERBATASAN DAN SARAN}

Peneliti memiliki informan yang minim, dikarenakan beberapa informan tidak berhasil peneliti temui, sehingga peneliti berharap peneliti selanjutnya dapat menambah jumlah informan yang bisa diwawancara. Selain itu, penelitian ini hanya berfokus pada hasil satu tahun anggaran. Peneliti selanjutnya diharapkan bisa memperluas penelitiannya dengan menambahkan tahun penelitian.

Pemerintah desa harus sering melakukan pembinaan terkait dengan pengelolaan keuangan desa melalui pemberian pelatihan-pelatihan akuntansi keuangan terhadap pengelolan keuangan agar sumber dayanya lebih baik dalam mengelola keuangan desa. Selain itu,masyarakat desa hendaknya lebih ikut serta dalam kegiatan yang ada di desa terlebih lagi pada saat musyawarah desa, untuk mendukung para aparatur desa agar lebih efisisen dan efektif dalam mengelola keuangan desa.

Pemerintah daerah hendaknya lebih tepat waktu dalam membuat atau mengeluarkan aturan mengenai perencanaan dan penganggaran desa pada tahun berkenaan, karena akan 
dijadikan patokan bagi pemerintah desa untuk membuat perencanaan dan penganggaran desa seperti halnya penetapan standar harga bahan pokok bangunan yang akan diinput juga pada Siskeudes.

Pemerintah desa juga hendaknya mengurangi anggaran belanja Dana Desa atau tidak jauh dari pendapatan yang akan didapatkan agar belanja Dana Desa dapat terealisasikan seluruhnya atau sesuai dengan yang dianggarkan, sehingga menyebabkan pendapatan dan belanja Dana Desa menjadi efektif. Selai itu, pemerintah desa juga hendaknya mengurangi kegiatan yang direncanakan, jika dianggap tidak mampu dalam melaksanakannya, sehingga tidak ada kegiatan yang belum terlaksana karena kebingungan pemerintah desa yang harus mendahulukan kegiatan yang mana akan dilaksanakan terlebih dahulu.

\section{DAFTAR PUSTAKA}

Badan Pengawasan Keuangan dan Pembangunan. 2015. Petunjuk Pelaksanaan, Bimbingan dan Konsultasi Pengelolaan Keuangan Desa. Jakarta.

Bupati Lombok Barat. 2016. Peraturan Bupati Nomor 15 Tahun 2016 tentang Pedoman Pengelolaan Keuangan Desa. Lombok Barat: Bupati Lombok Barat

Bupati Lombok Barat. 2007. Peraturan Daerah Nomor 7 Tahun 2007 tentang Persyaratan, Tatacara Pemilihan, Pengangkatan dan Pemberhentian Perangkat Desa. Lombok Barat: Bupati Lombok Barat

Gundono. 2017. Teori Organisasi. Yogyakarta: Andi. Edisi 4

Hasibuan, Malayu. 2004. Manajemen. Jakarta: PT. Bumi Aksara. Edisi Revisi

Hasibuan, Malayu. 2003. Manajemen Sumber Daya Manusia. Jakarta: PT. Bumi Aksara. Edisi Revisi Hal 244

Juliana, Endang. 2017. Efektivitas Pemanfaatan Dana Desa dalam Menunjang Pembangunan Pedesaan di Kabupaten Asahan. Universitas Sumatera Utara

Kambey, Edwien. 2017. Efektivitas Penggunaan Dana Desa dalam Pelaksanaan Pembangunan di Desa Karegesan Kecamatan Kauditan Kabupaten Minahasa Utara. Journal unsrat, Vol. 1 No. 1

Kementerian Dalam Negeri. 2006. Peraturan Menteri Dalam Negeri Nomor 13 Tahun 2006 tentang Pedoman Pengelolaan Keuangan Daerah. Jakarta:Departemen Dalam Negeri

Kementerian Dalam Negeri. 2018. Peraturan Menteri Dalam Negeri Nomor 20 Tahun 2018 tentang Pengelolaan Keuangan Desa. Jakarta:Departemen Dalam Negeri

Kementerian Dalam Negeri. 2018. Peraturan Menteri Desa Pembangunan Daerah Tertinggal, dan Transmigrasi Nomor 16 Tahun 2018 tentang Penetapan Prioritas Penggunaan Dana Desa. Jakarta:Departemen Dalam Negeri

Kusdewanti, A., Iwan, T., Ali, Djamhuri. 2017. Teori Ketundukan Gugatan Terhadap Agency Theory. Jakarta: yayasan rumah peneleh. Edisi ke 2. Hal 213

Mahsun, Mohamad. 2016. Pengukuran Kinerja Sektor Publik. Yogyakarta: BPFEYogyakarta. Edisi pertama. Hal 179

Miarso, Yusufhadi. 2007. Menyemai Benih Teknologi. Jakarta: Prenada Media Group

Sugiyono. 2017. Metode Penelitian Kualitatif. ALFABETA CV: Bandung

Sugiyono. 2017. Metode Penelitian Kuantitatif, Kualitatif dan R\&D. ALFABETA: Bandung

Turere. 2018. Efektivitas Dana Desa terhadap Peningkatan Kesejahteraan Masyarakat di Kecamatan Pineleng Kabupaten Minahasa. Jurnal Pembangunan Ekonomi dan Keuangan Daerah, Vol. 19 No. 6 